\title{
COMBINATIONS OF CHOLECALCIFEROL AND 25-HYDROXYCHOLECALCIFEROL AS VITAMIN D SOURCES IN WHITE LAYING HEN FEED DIETS
}

\author{
Combinações de colecalciferol e 25-hidroxicolecalciferol como fontes de \\ vitamina $\mathrm{D}$ em dietas para galinhas poedeiras leves
}

\author{
Diego Fernando Remolina Rivera ${ }^{1}$, Antonio Gilberto Bertechini ${ }^{2}$, Tiago Ferreira Birro Oliveira ${ }^{2}$, \\ Solange de Faria Castro ${ }^{2}$, Henrique Braga Oliveira², Manuel Fernando Bobadilla-Mendez ${ }^{2}$
}

\begin{abstract}
The effect of cholecalciferol $\left(\mathrm{D}_{3}\right)$ and 25-hydroxycholecalciferol $\left(25-\mathrm{OHD}_{3}\right)$ as isolated or associated sources of vitamin D (100\%-0\%, 75\%-25\%, 50\%-50\%, 25\%-75\%, 0\%-100\%) on the productive performance, egg quality, and bone characteristics was evaluated in white egg-laying hens fed two levels of calcium $(\mathrm{Ca})$ and phosphorus $(\mathrm{P})$ in the basal diet $(\mathrm{BD})(\mathrm{BD} 1=0.38 \%$ $\mathrm{Ca}-0.36 \%$ available $\mathrm{P}$ and $\mathrm{BD} 2=3.2 \% \mathrm{Ca}-0.30 \%$ available $\mathrm{P})$. Nine hundred and sixty Dekalb White hens (24 weeks old) were distributed into 80 cages, under a completely randomized factorial design for 16 weeks. The use of associated sources of vitamin D reduced the feed intake and feed conversion ratio, as well as BD1, which also increased the egg production and egg mass. The association of vitamin D sources with up to $50 \% 25-\mathrm{OHD}_{3}$ increased the eggshell percentage. There was interaction $(\mathrm{p}<0.05)$ between the sources of vitamin $\mathrm{D}$ and the concentrations of $\mathrm{Ca}$ and available $\mathrm{P}$, sources with at least $50 \% 25-\mathrm{OHD}$ increased ash percentage and bone radiographic densitometry (BRD) with BD1; in BD2 the use of 25-OHD ${ }_{3}$ as isolated vitamin $\mathrm{D}$ source increased BRD. The association of $\mathrm{D}_{3}$ and $25-\mathrm{OHD}_{3}$ improved the productive performance, increased the percentage of eggshell and had different positive effects on the bone characteristics that depend on the concentrations of Ca and available $\mathrm{P}$ in the balanced feed of white egg-laying hens.
\end{abstract}

Index terms: Vitamin sources, productive performance, eggshell quality, bone characteristics.

\section{RESUMO}

O objetivo desta pesquisa foi avaliar o efeito da suplementação de colecalciferol $\left(\mathrm{D}_{3}\right)$ e 25 hidroxicolecalciferol $\left(25-\mathrm{OHD}_{3}\right)$ como fontes isoladas ou associadas ( $100 \%-0 \% ; 75 \%-25 \% ; 50 \%-50 \% ; 25 \%-75 \% ; 0 \%-100 \%)$ de vitamina D sobre o desempenho, a qualidade de casca e as características ósseas, em galinhas poedeiras de ovos brancos de 24 semanas de idade alimentadas com duas concentrações de cálcio $(\mathrm{Ca})$ e fósforo disponível (Pdisp) na dieta basal (DB) (DB1 = 0,38\% $\mathrm{Ca}-0,36 \%$ Pdisp e DB2=3,2\% $\mathrm{Ca}-0,30 \%$ Pdisp), durante um período experimental de 16 semanas. Foram utilizadas 960 galinhas Dekalb White em delineamento inteiramente casualizado, com oito repetições e doze aves por unidade experimental. Os tratamentos foram constituídos de um fatorial (5x2), associações de vitamina D e concentrações de Ca e Pdisp. As fontes de vitamina D associadase a maior concentração de Ca e Pdisp diminuíram o consumo de ração e a conversão alimentar. Além disso, a maior concentração de Ca e Pdisp incrementou a produção e massa de ovo. A suplementação a partir de $50 \%$ de $25-\mathrm{OHD}_{3}$ entre as associações de vitamina $\mathrm{D}$ aumentou a porcentagem de casca do ovo. Houve interação entre as fontes de vitamina D e as concentrações de Ca e Pdisp. As fontes de vitamina D na DB1 com pelo menos $50 \%$ de $25-\mathrm{OHD}_{3}$ incrementaram a porcentagem de cinzas e a densitometria óssea radiográfica (BRD). A suplementação de $25-\mathrm{OHD}_{3}$ na DB2 como fonte isolada de vitamina D aumentou a BRD.

Termos para indexação: Fontes de vitamina, desempenho produtivo, qualidade de casca, caraterísticas ósseas.

\section{INTRODUCTION}

The high incidence of bone problems associated with osteoporosis in egg-laying hens housed in the battery position has generated concern in the scientific community about animal welfare associated with this production system (Rath et al., 2000). Moreover, problems with egg shell quality generate millions in losses to the poultry industry; thus, it is important to understand the factors that affect the internal and external quality of the egg (Roberts,
2004). Bone structure and egg shell quality are influenced by environmental, handling, and nutritional factors (Nys, 1999). Calcium, in addition to other functions, may be the most significant factor in eggshell formation and proper maintenance of the bone structure, considering this mineral constitutes $40 \%$ of the eggshell (Keshavarz, 2003) and that hydroxyapatite in bones constitutes $99 \%$ of the total $\mathrm{Ca}$ in the body of a bird (Johnston; Ivey 2002).

Thus, due to the physiological importance of $\mathrm{Ca}$, this mineral is regulated by hormone systems that modulate

\footnotetext{
${ }^{1}$ Universidade Federal de Lavras/UFLA - Departamento de Zootecnia/DZO - Cx. P. 3037 - 37200-000 - Lavras - MG - Brasil - renutro@gmail.com 2Universidade Federal de Lavras/UFLA - Departamento de Zootecnia/DZO - Lavras - MG - Brasil Received in january 7, 2014 and approved in august 20,2014
} 
physiological responses according to the plasma levels. Under a low concentration of $\mathrm{Ca}$, parathyroid hormone stimulates the activation of calcitriol $\left(1 \alpha, 25(\mathrm{OH})_{2} \mathrm{D}_{3}\right)$, which constitute the active form of vitamin $\mathrm{D}$ that acts to reabsorb $\mathrm{Ca}$ from the bones and kidney, and increases active transport in the intestine (Jhonston, Ivey 2002).

Precursors of $1 \alpha, 25(\mathrm{OH})_{2} \mathrm{D}_{3}$ can be obtained through the diet or synthesized in vivo through ultraviolet irradiation of 7-dehydrocholesterol. The physiologic reaction produces cholecalciferol $\left(\mathrm{D}_{3}\right)$ in animals and ergocalciferol $\left(\mathrm{D}_{2}\right)$ in plants; however, plasma proteins that transport $1 \alpha, 25(\mathrm{OH})_{2} \mathrm{D}_{3}$ precursors do not bind effectively to $\mathrm{D}_{2}$ in birds, thereby decreasing the effectiveness of this compound as a source of vitamin D (Soares, Kerr; Gray, 1995). Furthermore, in modern productions of laying hens the birds remain in battery cages,and therefore the physiological conversion of 7-dehydrocholesterol does not ensure sufficient $1 \alpha, 25(\mathrm{OH})_{2} \mathrm{D}_{3}$ for the birds (Goff, Horst, 1995). Consequently, supplementation of vitamin D for those birds found under these production circumstances is necessary (Bertechini, 2012).

During phases of greater egg production, the metabolic demand and $\mathrm{Ca}$ excretion via eggshell increase (Saunders-Blade et al., 2009) so that, efficient utilization of this mineral is crucial for bone health, eggshell quality, and productive performance of hens. However, under commercial conditions, clinical signs of $\mathrm{D}_{3}$ deficiency, such as cage fatigue and eggs with deformed eggshells, are commonly observed (Webster, 2004).

$\mathrm{D}_{3}$, dietary or endogenous, is not the active form of vitamin D. To become active, it has to be transported to the liver and the kidney after being absorbed in the small intestine along with the lipids of the $\operatorname{diet}$ (Combs, 2012). Hepatic and renal hydroxylations at positions 25 and $1 \alpha$, respectively, are the metabolic processes that convert $\mathrm{D}_{3}$ to $1 \alpha, 25(\mathrm{OH})_{2} \mathrm{D}_{3}$ and regulate vitamin $\mathrm{D}$ function in the body (Crenshaw et al., 2011). Hepatic hydroxylation of $\mathrm{D}_{3}$ produces 25 hydroxycholecalciferol $\left(25-\mathrm{OHD}_{3}\right)$, which is a metabolite with different characteristics than $\mathrm{D}_{3}$ that is currently available as a dietary source of vitamin D.

Different studies have been conducted evaluating vitamin $\mathrm{D}$ supplementation on performance and egg quality of laying hens. Hen layers supplemented with $37.50 \mu / \mathrm{kg}$ of $25-\mathrm{OHD}_{3}$ from week 65 to $75 \mathrm{and} 1.0 \mathrm{mg} / \mathrm{kg}$ of $1 \alpha, 25(\mathrm{OH})_{2} \mathrm{D}_{3}$ in diets containing $0.55 \% \mathrm{P}$ and $3.75 \%$ of $\mathrm{Ca}$ showed significant improvement in egg production (Frost, Roland,1990). Carlos and Edwards (1998), also observed an improvement in egg production in layers hens from 65 to 78 weeks of age, when they were fed a diet containing $5 \mathrm{mg} / \mathrm{kg}$ of $1 \alpha, 25(\mathrm{OH})_{2} \mathrm{D}_{3}$ with $3.0 \% \mathrm{Ca}$ and
$0.33 \%$ P. However, some studies found no difference in productive performance when evaluating $25-\mathrm{OHD}_{3}$ as an isolated source of vitamin D in egg-laying hens (Keshavarz 2003; Matila et al., 2005).

In broilers chickens some authors report positive effects on productive performance using $25-\mathrm{OHD}_{3}$ as a source of vitamin D in broiler chickens (Yarger et al., 1995; Fritts, Waldroup, 2003), including Brito et al. (2010), who determined that using $\mathrm{D}_{3}$ and $25-\mathrm{OHD}_{3}$ together produces better zootechnical results than using any of this compounds as individual sources. However, the effects of using $\mathrm{D}_{3}$ and $25-\mathrm{OHD}_{3}$ together as a dietary source of vitamin D has not been established in white egg-laying hens. Therefore, the aim of the present study was to determine the effects of using $\mathrm{D}_{3}$ and $25-\mathrm{OHD}_{3}$ as isolated or associated sources of vitamin $\mathrm{D}$ in different proportions on the productive performance, eggshell quality, and bone structure characteristics in white commercial egg-laying hens (24 to 40 weeks old) fed with two levels of $\mathrm{Ca}$ and available phosphorus (avaP) in the diet.

\section{MATERIAL AND METHODS}

The experiment was conducted at the Center for Research in Poultry Technology (CPTA/Convention Federal University of Lavras), located in the Lavras municipality, southern region of the state of Minas Gerais, Brazil, at an altitude of 910 meters above sea level, latitude $21^{\circ} 14^{\prime} 30^{\prime \prime}$ (S), longitude $45^{\circ} 00^{\prime} 10^{\prime \prime}$. All procedures performed during the experimental period were approved by the bioethics committee of the Federal University of Lavras.

Nine hundred and sixty Dekalb White hens (24 weeks old) were housed in coops with a natural environment. The birds were distributed into 80 cages, adopting a density of $375 \mathrm{~cm}^{2} /$ bird per cage. Water and balanced feed were provided ad libitum, and recommendations for the lighting and management program were followed, based on Dekalb White management guide (Institut de selection animale B.V., 2009). A completely randomized factorial design $(5 \times 2)$ was used, considering five vitamin D sources and two levels of $\mathrm{Ca}$ and available $\mathrm{P}$ in the diet, with eight repetitions and 12 hens per plot, for 16 weeks of research.

The experimental diets were completely vegetarian (based on corn and soybean meal), isocaloric, and isoproteic and were supplemented with vitamins (vitamin premix without vitamin D) and minerals (mineral premix). Recommendations for minimal nutrients suggested by Rostagno et al. (2005) were followed, except for $\mathrm{Ca}$ and avaP, to meet the nutritional requirements of the birds 
during the experimental period. Two basal diets (BD) were formulated (Table 1), with different concentrations of $\mathrm{Ca}$ and avaP while maintaining the ratio between both nutrients, according to the experimental design: $3.8 \% \mathrm{Ca}$ with $0.36 \%$ avaP (BD1) and $3.2 \%$ Ca with $0.30 \%$ avaP (BD2). In BD1 and BD2, five different evaluated sources of vitamin $\mathrm{D}$ were added.

Table 1 - Basal diets percentage and nutritional composition.

\begin{tabular}{lcc}
\hline \multirow{2}{*}{\multicolumn{1}{c}{ Ingredients }} & \multicolumn{2}{c}{ Percentage (\%) } \\
\cline { 2 - 3 } & BD1 & BD2 \\
\hline Corn & 65.652 & 65.652 \\
Soybean meal & 22.356 & 22.356 \\
Soybean oil & 1.000 & 1.000 \\
Dicalcium phosphate & 1.469 & 1.144 \\
Limestone & 8.813 & 7.731 \\
Salt & 0.358 & 0.358 \\
Vitamin premix ${ }^{1}$ & 0.100 & 0.100 \\
Mineral ore & 0.100 & 0.100 \\
DL-methionine 99\% & 0.072 & 0.072 \\
Vitamin D source & 0.080 & 0.080 \\
Kaolin & - & 1.407 \\
Total & 100 & 100 \\
\hline \multicolumn{1}{c}{ Calculated Analysis } & \\
\hline Metabolizable Energy (kcal/kg) & 2830 & 2830 \\
Crude Protein (\%) & 15.850 & 15.850 \\
Digestible Methionine (\%) & 0.307 & 0.307 \\
Digestible Methionine + Cistein (\%) & 0.540 & 0.540 \\
Digestible Lysine (\%) & 0.720 & 0.720 \\
Calcium (\%) & 3.800 & 3.200 \\
Available Phosphorus (\%) & 0.360 & 0.300 \\
Sodium (\%) & 0.180 & 0.180 \\
\hline Var & &
\end{tabular}

${ }^{1}$ Vitamin mix provided the following per kg of diet:Vitamin A, 7.000 U.I;Vitamin E, 8 U.I; Vitamin $\mathrm{K}_{3}, 1 \mathrm{mg}$; Vitamin $\mathrm{B}_{12}, 10$ mg; Folic acid, $300 \mathrm{mg}$; Pantothenic acid, $7.000 \mathrm{mg}$; Biotin, 20 mg;Niacin20.000 mg; Pyridoxine, 1.000 mg; Riboflavin, 4.000 $\mathrm{mg}$; Thiamin1.000 mg. ${ }^{2}$ Mineral mix provided the following per $\mathrm{kg}$ of diet: $10.000 \mathrm{mg} \mathrm{Cu} ; 50.000 \mathrm{mg} \mathrm{Fe} ; 800 \mathrm{mg} \mathrm{I}, 65.000 \mathrm{~g}$ $\mathrm{Mn} ; 60.000 \mathrm{mg} \mathrm{Zn;} 300 \mathrm{mg}$ Se.

The vitamin $\mathrm{D}$ was used at $1.600 \mathrm{IU} / \mathrm{kg}$ of diet according to the suggested nutritional value by Rostagno et al., (2005) for white egg layers in production phase, $\mathrm{D}_{3}$ and $25-\mathrm{OHD}_{3}$ at $2.000 .000 \mathrm{UI}$ per kilogram of product were provided by DSM Nutritional Products (Brazil), these products permitted the production of the vitamin $\mathrm{D}$ sources referred at the experimental design (Table 2).

Table 2 - Vitamin D sources composition according to the experimental design.

\begin{tabular}{ccccc}
\hline \multicolumn{2}{c}{$\begin{array}{c}\text { Vitamin D } \\
\text { source }\end{array}$} & \multicolumn{2}{c}{$\begin{array}{c}\text { Nutrient } \\
\text { concentration }\end{array}$} & $\begin{array}{c}\text { Factorial } \\
\text { combination }\end{array}$ \\
\cline { 1 - 4 }$\%$ & $\%$ & $\%$ & $\%$ & \\
$\mathrm{D}^{1}{ }^{1}$ & $25-\mathrm{OHD}_{3}{ }^{2}$ & $\mathrm{Ca}$ & Available P & \\
\hline 100 & - & 3.80 & 0.36 & 1 \\
75 & 25 & 3.80 & 0.36 & 2 \\
50 & 50 & 3.80 & 0.36 & 3 \\
25 & 75 & 3.80 & 0.36 & 4 \\
- & 100 & 3.80 & 0.36 & 5 \\
\hline 100 & - & 3.20 & 0.30 & 6 \\
75 & 25 & 3.20 & 0.30 & 7 \\
50 & 50 & 3.20 & 0.30 & 8 \\
25 & 75 & 3.20 & 0.30 & 9 \\
- & 100 & 3.20 & 0.30 & 10 \\
\hline
\end{tabular}

${ }^{1}$ Cholecalciferol at 2.000.000 IU per kilogram of product.

225 -Hydroxycholecalciferol at 2.000.000 IU per kilogram of product.

Feed intake, egg production, egg weight, egg mass, and feed conversion were recorded to evaluate the birds' productive performance. To analyze the egg quality, the percentage of eggshell problems was calculated using the method described by Tactacan et al., (2009), which allowed quantification of the percentage of cracked eggs and soft eggshells produced daily. In addition, the percentage of yolk, albumen, and eggshell, as well asthe specific gravity of the eggs were determined using eight eggs per repetition, which were selected daily and randomly from the total eggs collected during the last 2 days of every week. Eggs were weighed individually on a scale to the nearest $0.0001 \mathrm{~g}$ and were then broken. The yolk of each egg was separated and weighed; the respective eggshell was washed and air-dried for subsequent measurement of the weight without the inner membrane. The albumen weight was calculated by the difference between the total weight of each egg and the sum of the weight of the yolk and eggshell. Thereafter, the weight of each egg component was transformed to the percentage of the total weight of each egg analyzed. The 
specific gravity was determined according to the method implemented by Araujo et al., (2008).

At the end of the experiment, one bird per plot was sacrificed by cervical dislocation, and the tibias were removed to determine the bone ash and $\mathrm{Ca}$ concentrations, using the methods described by AOAC (2005). In addition, the tibias were analyzed via bone densitometry, the methods, procedure and elements described by Barreiro et al., (2009) were followed; the analyzed tibias and the aluminum scale were imaged on the same film with X-ray equipment (Tridoro 812E Siemens), calibrated with a focus-film distance of $25 \mathrm{~cm}$, and adjusted to $70 \mathrm{kVp}$ with 0.3 seconds exposure time in photographic film (Kodak $24 \times 18 \mathrm{~cm})$. Once the radiographs were obtained, they were processed in aA/T2000 XR (Air Techniques) developer, with a 4-minute processing time. The radiographs were digitized by a scanner (Kodak PS50) (with 300 dots per inch (DPI) resolution, 26\% brightness, and 68\% contrast) and were stored in digital archives with TIF extension. Radiographs were then read to determine the density of the bone pieces with respect to the aluminum scale, using the free Image J 1.4 software, which has the histogram tool that allows analysis of the radiographic density of the selected area. The histograms are distributed on a grey scale that has 256 shades, where 0 represents black and 256 represents white. The bone density was measured in the center area of the bone, and the bone densitometry results were expressed in millimeters of aluminum (mmAl).

The obtained data were subjected to variance analysis using the SISVAR 4.5 software, as described by Ferreira et al., (2011). The F test $(\mathrm{p}<0.05)$ was used to compare means between the concentrations of $\mathrm{Ca}$ and avaP in the diet. The Scott Knott test $(\mathrm{p}<0.05)$ was used to compare the sources of vitamin D.

\section{RESULTS AND DISCUSSION}

There was no interaction ( $p>0.05)$ between sources of vitamin $\mathrm{D}$ and concentrations of $\mathrm{Ca}$ and available $\mathrm{P}$ for any of the productive variables assessed in the experiment. The association of $\mathrm{D}_{3}$ with $25-\mathrm{OHD}_{3}$ produces a lower $(p<0.05)$ feed intake and feed conversion ratio than when using these sources of vitamin D individually. BD1 reduced $(p<0.05)$ the feed intake and feed conversion; additionally increased the percentage of production and egg mass (Table 3 ).

The reduced feed intake suggests that the combination of $\mathrm{D}_{3}$ and $25-\mathrm{OHD}_{3}$ is more effective for meeting vitamin $\mathrm{D}$ requirements and maximizing the use of dietary $\mathrm{Ca}$. The effect on feed intake explains the improved feed conversion and agrees with the results found by
Brito et al. (2010), who determined that the combined use of these same sources of vitamin D improves the productive performance of broiler chickens in all phases of production. Other researchers have utilized isolated $\mathrm{D}_{3}$ and $25-\mathrm{OHD}_{3}$ in diets for egg-laying hens, reporting different effects of $25-\mathrm{OHD}_{3}$ as an isolated source of vitamin D; Salvador et al. (2009), found improved feed conversion using $2756 \mathrm{IU} / \mathrm{kg}$ vitamin D, and Keshavarz (2003), reported no significant effect on the performance of egg-laying hens using $2760 \mathrm{IU} / \mathrm{kg}$ vitamin $\mathrm{D}$. In another experiment, Hernández et al. (2001), used $2750 \mathrm{IU} / \mathrm{kg} \mathrm{D}{ }_{3}$ to meet the vitamin $\mathrm{D}$ requirements of egg-laying hens and also supplemented with $2760 \mathrm{IU} / \mathrm{kg} 25-\mathrm{OHD} 3$ without observing effects on the productive performance of the assessed birds. The studies mentioned above used higher levels of vitamin $\mathrm{D}$, which is necessary for further testing of the association between sources at various levels of dietary supplementation. Importantly, the NRC (1994) recommends the use of $375 \mathrm{IU} / \mathrm{kg}$ vitamin $\mathrm{D}$; genetic considerations in the Dekalb White management guide (Institut de selection animale B.V., 2009) suggest the use of $1650 \mathrm{IU} / \mathrm{kg}$ and Rostagno et al. (2005), observed that $1600 \mathrm{IU} / \mathrm{kg}$ is sufficient to meet the requirements for vitamin $\mathrm{D}$ in egg-laying hens.

BD1, taking into account the feed intake, allowed the daily consumption of $4.1 \mathrm{~g}$ of $\mathrm{Ca}$ and $0.39 \mathrm{~g}$ of avaP per bird, which is an amount similar to that suggested by the Dekalb White 2009 (Institut de selection animale B.V., 2009) management guide ( $4.2 \mathrm{~g} \mathrm{Ca} / \mathrm{bird} /$ day and 0.44 ava $\mathrm{P} /$ bird/day) and to the recommendation by Rostagno et al., (2005) of $4.02 \mathrm{~g}$ Ca with $0.37 \mathrm{~g}$ avaP bird/day for white hens in production. According to other authors, a daily $\mathrm{Ca}$ consumption of $3.25 \mathrm{~g}$ with $0.25 \mathrm{~g}$ of avaP(NRC, 1994) or $3.63 \mathrm{~g}$ Ca with $0.43 \mathrm{avaP}$ (Keshavarz, 2003) may be enough to ensure efficiency in the productive phase of egg-laying hens. Based on the results of the experiment, a consumption of $4.1 \mathrm{~g} / \mathrm{bird} / \mathrm{day} \mathrm{Ca}$ and $0.39 \mathrm{~g} / \mathrm{bird} / \mathrm{day}$ produces better zootechnical performance, except for egg weight, than does consumption of $3.45 \mathrm{~g} \mathrm{Ca} / \mathrm{bird} /$ day and $0.33 \mathrm{~g}$ avaP/bird/day.

According to Safaa et al., (2008), increasing the daily $\mathrm{Ca}$ consumption from $4.06 \mathrm{~g}$ to $4.67 \mathrm{~g}$ improves egg production, egg mass, and feed conversion, without affecting the egg weight. Castillo et al., (2004) determined that although egg production is not affected by the level of $\mathrm{Ca}$ in the diet, $\mathrm{Ca}$ decreases feed intake. This situation occurred in this experiment and was similar to the linear response, described by Roland et al., (1996), between feed consumption and the level of dietary Ca. 
Table 3 - Effects over the productive performance, eggshell and bone quality of white laying hens supplemented with different sources of vitamin D on diets with two calcium and available phosphorus concentrations.

\begin{tabular}{|c|c|c|c|c|c|c|c|c|}
\hline \multirow[t]{2}{*}{ Variable } & \multicolumn{2}{|c|}{$\mathrm{Ca} /$ Available $\mathrm{P}(\%)^{2}$} & \multicolumn{6}{|c|}{$\begin{array}{l}\text { Vitamin D sources associations } \\
\mathrm{D}_{3} / 25 \mathrm{OHD}_{3}(\%)^{1}\end{array}$} \\
\hline & $3.8-0.36$ & $3.2-0.3$ & $100 / 0$ & $75 / 25$ & $50 / 50$ & $25 / 75$ & $0 / 100$ & C.V. $(\%)$ \\
\hline \multicolumn{9}{|c|}{ Productive Performance } \\
\hline Feed intake (g/hen*day) & $108.34^{\mathrm{A}}$ & $108.85^{\mathrm{B}}$ & $108.81^{\mathrm{b}}$ & $108.46^{\mathrm{a}}$ & $108.41^{\mathrm{a}}$ & $108.45^{\mathrm{a}}$ & $108.9^{\mathrm{b}}$ & 0.75 \\
\hline Egg production (\% egg/ hen*day) & $91.44^{\mathrm{A}}$ & $90.79^{\mathrm{B}}$ & 91.04 & 91.15 & 91.26 & 91.20 & 90.92 & 1.21 \\
\hline Egg weigth (g) & 62.34 & 62.21 & 61.90 & 62.26 & 62.45 & 62.42 & 62.34 & 1.87 \\
\hline Feed:egg ratio(g feed/g egg) & $1.904^{\mathrm{A}}$ & $1.930^{\mathrm{B}}$ & $1.932^{\mathrm{b}}$ & $1.914^{\mathrm{a}}$ & $1.905^{\mathrm{a}}$ & $1.908^{\mathrm{a}}$ & $1.926^{\mathrm{b}}$ & 2.10 \\
\hline Egg mass $(\mathrm{g})$ & $57.02^{\mathrm{A}}$ & $56.53^{\mathrm{B}}$ & 56.46 & 56.75 & 57.10 & 56.96 & 56.70 & 2.09 \\
\hline \multicolumn{9}{|c|}{ Eggshell Quality } \\
\hline Eggshell problems ${ }^{\#}(\%)$ & $0.57^{\mathrm{A}}$ & $0.73^{\mathrm{B}}$ & 0.76 & 0.64 & 0.65 & 0.57 & 0.64 & 3.19 \\
\hline Specific gravity $\left(\mathrm{g} / \mathrm{cm}^{3}\right)$ & 1.0849 & 1.0846 & 1.0843 & 1.0850 & 1.0853 & 1.0849 & 1.0844 & 0.28 \\
\hline Yolk (\%) & 25.37 & 25.38 & 25.35 & 25.42 & 25.33 & 25.36 & 25.39 & 1.67 \\
\hline Albumen (\%) & 64.01 & 64.15 & 64.18 & 63.76 & 64.02 & 64.13 & 64.10 & 3.76 \\
\hline Eggshell (\%) & $10.60^{\mathrm{A}}$ & $10.46^{\mathrm{B}}$ & $10.45^{\mathrm{b}}$ & $10.60^{\mathrm{a}}$ & $10.63^{\mathrm{a}}$ & $10.50^{\mathrm{b}}$ & $10.48^{\mathrm{b}}$ & 3.61 \\
\hline \multicolumn{9}{|c|}{ Bone Quality } \\
\hline Calcium (\%) & $36.39^{\mathrm{A}}$ & $34.70^{\mathrm{B}}$ & 34.82 & 35.89 & 35.47 & 36.20 & 35.33 & 5.17 \\
\hline $\operatorname{Ash}(\%)^{*}$ & 54.90 & 53.74 & 53.31 & 53.70 & 54.58 & 55.43 & 54.58 & 2.17 \\
\hline Bone densitometry $(\mathrm{mm} \mathrm{Al})^{*}$ & 2.64 & 2.51 & 2.47 & 2.49 & 2.60 & 2.64 & 2.67 & 10.12 \\
\hline
\end{tabular}

${ }^{1}$ Means with different lowercase letter superscripts are significantly different by Skott-Knott test $(\mathrm{p}<0.05)$.

${ }^{2}$ Means with different capital letter superscripts are significantly different by $\mathrm{F}$ test $(\mathrm{p}<0.05)$.

${ }^{\#}$ Cracked eggs and soft eggshells.

*Interaction $(p<0.05)$ between the sources of vitamin $\mathrm{D}$ and the concentrations of $\mathrm{Ca}$ and available $\mathrm{P}$ in the feed (Table 4).

There was no interaction $(\mathrm{p}>0.05)$ between the sources of vitamin $\mathrm{D}$ and the concentrations of $\mathrm{Ca}$ and avaP for any of the assessed variables of eggshell quality. Associated sources of vitamin D composed of $25 \%$ and $50 \% 25-\mathrm{OHD}_{3}$ generated a greater $(\mathrm{p}<0.05)$ percentage of eggshell. BD1 increased $(\mathrm{p}<0.05)$ the percentage of eggshell and decreased $(p<0.05)$ the percentage of eggshell problems (Table 3).

According to Bar and Hurtwitz (1973), vitamin $\mathrm{D}$ is possibly involved in $\mathrm{Ca}$ transport across the uterine membrane in birds. Associated sources consisting of up to $50 \% 25 \mathrm{OHD}_{3}$ increased the eggshell percentage in the eggs analyzed, which indicates that the combination of the sources has a greater biological activity for this function. These results are similar to those found by Hernandez et al., (2001), who reported increased eggshell thickness using a source of vitamin D composed of $\mathrm{D}_{3}$ and $25-\mathrm{OHD}_{3}$. By contrast, Salvador et al., (2009) established that there are no differences in the yolk, white, eggshell, specific gravity, and eggshell thickness percentage using any of the isolated sources, a conclusion that confirms the results obtained in this study. The increase in eggshell percentage was also generated by BD1, which is a similar finding to that reported by Keshavarz (1998), who observed an increase in eggshell when the Ca consumption increased from $3.51 \mathrm{~g}$ to 4.25 g per hen daily. By contrast, Rao et al., (2003) found no differences in weight or eggshell upon increasing the daily $\mathrm{Ca}$ consumption from $3.51 \mathrm{~g}$ to $4.85 \mathrm{~g}$ per bird.

The decrease in cracked eggs and soft eggshells under the consumption of $4.1 \mathrm{~g} \mathrm{Ca} /$ bird/day and $0.39 \mathrm{~g}$ avaP/bird/day differs from the results found by Keshavarz and Nakajima (1993), who established that consuming $3.77 \mathrm{~g} \mathrm{Ca} / \mathrm{bird} /$ day is sufficient for producing eggshells of optimal quality.

There was an interaction $(\mathrm{p}<0.05)$ between the sources of vitamin $\mathrm{D}$ and the concentrations of $\mathrm{Ca}$ and available $\mathrm{P}$ in the feed with respect to the percentage of 
ash and the radiographic bone densitometry of the analyzed tibias; BD1 increased $(\mathrm{p}<0.05)$ the percentage of $\mathrm{Ca}$ in analyzed tibias (Table 3 ).

An increased percentage of ash $(p<0.05)$ was found in tibias from birds fed BD1 and vitamin D source with at least $50 \%$ of $25 \mathrm{OHD}_{3}$. There were no significant differences $(p>0.05)$ in the percentage of ash in the tibias of birds fed BD2. Associated sources of vitamin D with more than $25 \%$ of $25-\mathrm{OHD}_{3}$ yielded a higher percentage of ash $(\mathrm{p}>0.05)$ in the tibias of birds fed with BD1.

The bone densitometry increased in tibias from birds that received BD1 with at least $50 \%$ of $25-\mathrm{OHD}_{3}$. There was an increased $(p<0.05)$ bone densitometry in the tibias of birds fed BD2 with $25-\mathrm{OHD}_{3}$ asisolated source of vitamin D. Associated sources with $50 \%$ and $75 \%$ $25-\mathrm{OHD}_{3}$ in $\mathrm{BD} 1$ increased $(\mathrm{p}<0.05)$ the bone densitometry (Table 4).

To increase the plasma concentration of $\mathrm{Ca}$, vitamin $\mathrm{D}$ promotes absorption of the mineral from the diet or bones (Johnston, Ivey 2002); however, Ca and the ratio of $\mathrm{Ca}$ to avaP in the diet affect the bone structure composition in egg-laying hens (Cheng; Coon, 1990).
This feature is reflected in the response of the evaluated bone characteristics; the ash percentage and the bone densitometry were greater when using sources with at least $25 \% 25-\mathrm{OHD}_{3}$ in $\mathrm{BD} 1$ and $100 \% 25-\mathrm{OHD}_{3}$ as a vitamin $\mathrm{D}$ source in $\mathrm{BD} 2$. Additionally, using $25-\mathrm{OHD}_{3}$ as an isolated source produced the same results, regardless of the concentration of $\mathrm{Ca}$ and avaP in the diet. According to these data, $25-\mathrm{OHD}_{3}$ is an alternative for improving the bone structure characteristics of white egg-laying hens during the phase of highest egg production. Keshavarz (2003), found no difference in the ash percentage when experimenting with $25-\mathrm{OHD}_{3}$ (as an isolated source) and different concentrations of $\mathrm{Ca}$ and avaP in the diet. This result was confirmed by Salvador et al. (2009), who also discovered that the percentage of $\mathrm{Ca}$ in the tibias of egglaying hens increases when $\mathrm{D}_{3}$ is used as the only source of vitamin $\mathrm{D}$. That finding was not observed in this study, as the percentage of $\mathrm{Ca}$ in the tibia was the same using all evaluated sources of vitamin $\mathrm{D}$, contrasting with the increase observed with BD1. Schreiweis et al., (2003) observed that the mineral content and bone density of tibias decrease linearly with reduced $\mathrm{Ca}$ consumption.

Table 4 - Effects over the bone characteristics of white laying hens supplemented with different sources of vitamin D on diets with two calcium and available phosphorus concentrations.

\begin{tabular}{|c|c|c|c|c|c|}
\hline \multirow[t]{2}{*}{$\mathrm{Ca} /$ Available $\mathrm{P}(\%)^{1}$} & \multicolumn{5}{|c|}{$\begin{array}{c}\text { Vitamin D sources associations } \\
\mathrm{D}_{3} / 25 \mathrm{OHD}_{3}(\%)^{2} \\
\end{array}$} \\
\hline & $100 / 0$ & $75 / 25$ & $50 / 50$ & $25 / 75$ & $0 / 100$ \\
\hline & \multicolumn{5}{|c|}{$-\operatorname{Ash}(\%)-$} \\
\hline $3.8 / 0.36$ & $53.27^{\mathrm{bA}}$ & $53.88^{\mathrm{bA}}$ & $55.94^{\mathrm{aA}}$ & $56.37^{\mathrm{aA}}$ & $55.07^{\mathrm{aA}}$ \\
\hline \multirow[t]{2}{*}{$3.2 / 0.3$} & $53.36^{\mathrm{aA}}$ & $53.53^{\mathrm{aA}}$ & $53.23^{\mathrm{aB}}$ & $54.49^{\mathrm{aB}}$ & $54.10^{\mathrm{aA}}$ \\
\hline & \multicolumn{5}{|c|}{ - Bone radiographic densitometry $(\mathrm{mm} \mathrm{Al})$ - } \\
\hline $3.8 / 0.36$ & $2.49^{\mathrm{bA}}$ & $2.46^{\mathrm{bA}}$ & $2.76^{\mathrm{aA}}$ & $2.91^{\mathrm{aA}}$ & $2.60^{\mathrm{aA}}$ \\
\hline $3.2 / 0.3$ & $2.46^{\mathrm{bA}}$ & $2.53^{\mathrm{bA}}$ & $2.44^{\mathrm{bB}}$ & $2.37^{\mathrm{bB}}$ & $2.74^{\mathrm{aA}}$ \\
\hline
\end{tabular}

${ }^{1}$ Within a row, means with different capital letter superscripts are significantly different by $\mathrm{F}$ test $(\mathrm{p}<0.05) .{ }^{2}$ Within a column, means with different lowercase letter superscripts are significantly different by Skott-Knott test $(\mathrm{p}<0.05)$. 


\section{CONCLUSIONS}

The associated use of $\mathrm{D}_{3}$ and $25-\mathrm{OHD}_{3}$ improves feed conversion in white egg-laying hens. Vitamin D sources associated with up to $50 \% 25-\mathrm{OHD}_{3}$ increase the percentage of eggshell in eggs. There is a differential response between combinations of the studied vitamin D sources with respect to the bone mineral content and bone density, depending on the concentration of $\mathrm{Ca}$ and available $\mathrm{P}$ formulated in the diet, except when $25-\mathrm{OHD}_{3}$ is used as the only source of vitamin D in feed. From week 24 to 40 of production in the laying cycle of white hens, diets with $3.8 \% \mathrm{Ca}$ and $0.36 \%$ available $P$ better meet the nutritional requirements, compared with levels of $3.2 \% \mathrm{Ca}$ and $0.30 \%$ available $\mathrm{P}$.

\section{REFERENCES}

AOAC INTERNATIONAL; HORWITZ, W. Official Methods of Analysis of the AOAC International. Gaithersburg, MD: AOAC International, 2005. p.21-22.

ARAUJO, D. D. et al. Farelo de trigo e complexo enzimático na alimentação de poedeiras semipesadas na fase de produção. Revista Brasileira de Zootecnia, 37(5):843-848, 2008.

BAR, A.; HURWITZ, S. Uterine calcium-binding protein in the laying fowl. Comparative Biochemistry and Physiology Part A: Molecular \& Integrative Physiology, 45A:579-586, 1973.

BARREIRO, F.R. et al. Densitometric and biochemical values of broiler tibias at different ages. Poultry Science, 88(12):2644-2648, 2009.

BERTECHINI, A.G. Nutrição de monogástricos. $2^{\mathrm{a}}$ Edição Lavras: Editora UFLA, 2012. 373 p.

BRITO, J. Á. G. D. et al. Efeito da vitamina D3 e 25-hidroxi-colecalciferol sobre o desempenho, o rendimento de carcaça e a morfologia intestinal de frangos de corte1. Revista Brasileira de Zootecnia, 39(12):2656-2663, 2010.

CARLOS, A.B.; EDWARDS, H.M. The effects of 1,25-dihydroxycholecalciferol and phytase on the natural phytate phosphorus utilisation by laying hens. Poultry Science, 77(6):850-858, 1998.

CASTILLO, C. et al. Biological and economic optimum level of calcium in White Leghorn laying hens. Poultry Science, 83(6):868-872, 2004.
COMBS, G.F. The vitamins. San Diego: Editora

Elservier, 2012, $570 \mathrm{p}$.

CHENG, T. K.; COON, C. N. Effect of calcium source, particle size, limestone solubility in vitro, and calcium intake level on layer bone status and performance. Poultry Science, 69(12):2214-2219, 1990.

CRENSHAW, T. D. et al. A novel pathway for vitamin D-mediated phosphate homeostasis: Implications for skeleton growth and mineralization. Journal of Animal Science, 89(7):1957-1964, 2011.

FERREIRA, D. F. Sisvar: a computer statistical analysis system. Ciência e Agrotecnologia, 35(6):1039-1042, 2011.

FRITTS, C. A.; WALDROUP, P. W. Effect of source and level of vitamin $d$ on live performance and bone development in growing broilers. The Journal of Applied Poultry Research, 12(1):4552, 2003.

FROST, T.J.; ROLAND Sr, D.A. Influence of vitamin D3, $1 \alpha$-hydroxyvitamin $\mathrm{D}_{3}$, and 1-25-dihydroxyvitamin $\mathrm{D}_{3}$ on eggshell quality, tibia strength, and various production parameters in commercial laying hens. Poultry Science, 69(11):2008-2016, 1990.

GOFF, J.P.; HORST, R.L. Assessing adequacy of cholecalciferol supplementation in chicks using plasma cholecalciferol metabolite concentrations as an indicator. Journal of Nutrition, 125(5):1351-1357, 1995.

HERNÁNDEZ, M. G. et al. Mejoramiento de la calidad del cascarón con 25 hidroxicolecalciferol [25-(OH) D3] en dietas de gallinas de primero y segundo ciclos. Veterinaria México, 32(3):167-174, 2001.

INSTITUT DE SELECTION ANIMALE B.V. Dekalb White: Guía de manejo de la nutrición de ponedoras comerciales. Boxmeer, ISA Hendrix Genetics, 2009-10. $24 \mathrm{p}$.

JOHNSTON, M. S.; IVEY, E. S. Parathyroid and ultimobranchial glands: Calcium metabolism in birds. Seminars in Avian and Exotic Pet Medicine.11(2):84-93, 2002. 
KESHAVARZ, K. Further investigations on the effect of dietary manipulation of protein, phosphorus, and calcium for reducing their daily requirement for laying hens. Poultry Science, 77(9):1333-1346, 1998.

. A comparison between cholecalciferol and 25-OH-cholecalciferol on performance and eggshell quality of hens fed different levels of calcium and phosphorus. Poultry Science, 82(9):1415-1422, 2003.

KESHAVARZ, K.; NAKAJIMA, S. Re-evaluation of calcium and phosphorus requirements of laying hens for optimum performance and eggshell quality. Poultry Science,72(1):144-153,1993.

MATTILA, P. et al. Effect of vitamin D2 and D3enriched diets on egg vitamin D content, production, and bird condition during an entire production period. Poultry Science, 83(3): 433-440,2005.

NRC. Nutrient requirement of poultry. 9a ed. Washington, DC: National Academic Science, 1994. $155 \mathrm{p}$.

NYS, Y. Nutritional factors affecting eggshell quality. Czech Journal of Animal Science, 44(3):135-143, 1999.

PHADNIS, R.; NEMERE, I. Direct, rapid effects of 25-hydroxyvitamin D3 on isolated intestinal cells. Journal of Cellular Biochemistry, 90(2):287-293, 2003.

RAO, S. V. R. et al. Requirement of calcium for commercial broilers and white leghorn layers at low dietary phosphorus levels. Animal Feed Science Technology, 106(1-4):199-208, 2003.

RATH, N. et al. Factors regulating bone maturity and strength in poultry. Poultry Science, 79(7):1024-1032, 2000 .

ROBERTS, J. R. Factors affecting egg internal quality and egg shell quality in laying hens. Journal of Poultry Science, 41(3):161-177, 2004.
ROLAND, D. A. et al. Influence of calcium and environmental temperature on performance of firstcycle (phase 1) commercial leghorns. Poultry Science, 75(1):62-68, 1996.

ROSTAGNO, H. S. et al. Tabelas brasileiras para aves e suínos: composição de alimentos e exigências nutricionais. Viçosa: UFV/DZO, 2005. 186p.

SAFAA, H. M. et al.Effects of the levels of methionine, linoleic acid, and added fat in the diet on productive performance and egg quality of brown laying hens in the late phase of production. Poultry Science, 87(8):15951602, 2008.

SALVADOR, D. et al. Vitaminas D e C para poedeiras na fase inicial de produção de ovos. Revista Brasileira de Zootecnia, 38(5):.887-892, 2009.

SAUNDERS-BLADES, J. L. et al. The effect of calcium source and particle size on the production performance and bone quality of laying hens. Poultry Science, 88(2):338-353, 2009.

SCHREIWEIS, M. et al. The use of densitometry to detect differences in bone mineral density and content of live White Leghorns fed varying levels of dietary calcium. Poultry Science, 82(8):1292-1301, 2003.

SOARES, J. H.; KERR, J. M.; GRAY, R. W. 25-Hydroxycholecalciferol in poultry nutrition. Poultry Science, 74(12):1919-1934, 1995.

TACTACAN, G. B. et al. Performance and welfare of laying hens in conventional and enriched cages. Poultry Science, 88(4):698-707, 2009.

WEBSTER, A. Welfare implications of avian osteoporosis. Poultry Science, 83(2):184-192, 2004.

YARGER, J. G. et al. Safety of 25-hydroxycholecalciferol as a source of cholecalciferol in poultry rations. Poultry Science, 74(9):1437-1446, 1995. 